\title{
TRADISI KASAMBU DAN FUNGSINYA PADA MASYARAKAT MUNA SULAWESI TENGGARA
}

\section{The Kasambu Tradition and its Function in The Muna Society, South East Sulawesi}

\author{
Masgaba \\ Balai Pelestarian Nilai Budaya Makassar \\ JL. Sultan Alauddin / Tala Salapang Km 7, Makassar 90211 \\ Email: masgabaumar@yahoo.co.id
}

Naskah diterima tanggal 24 Desember 2014. Naskah direvisi tanggal 16 Februari 2015. Naskah disetujui tanggal 22 Mei 2015

\begin{abstract}
Abstrak
Artikel ini bertujuan untuk menggambarkan prosesi pelaksanaan upacara kasambu dan menjelaskan fungsinya bagi kehidupan masyarakat Muna. Data diambil dari hasil penelitian deskriptif kualitatif dengan teknik pengumpulan data dengan wawancara, pengamatan, dan studi pustaka. Hasil penelitian menunjukan, bahwa kasambu merupakan ritual yang dilakukan masyarakat Muna pada usia 7-8 kehamilan pertama seorang perempuan. Pada masa ke kinian ritual ini masih eksis walaupun ada pergeseran dalam hal penggunaan jasa sando pada saat melahirkan digantikan oleh tenaga medis. Ritual kasambu dilakukan agar orang tua dan anak dapat terhindar dari malapetaka yang mungkin akan menimpanya, dan melahirkan dengan selamat. Prosesinya merupakan sinkretisme antara ajaran Islam yang dianutnya dengan kepercayaan leluhur mereka, dimana Sando merupakan orang yang mengetahui tata cara upacara dan imam bertindak sebagai pemimpin doa keselamatan.
\end{abstract}

Kata kunci: kasambu, ritual, fungsi, masyarakat Muna.

\begin{abstract}
This article aims to describe the procession of kasambu ceremony and to explain its function for the Muna society. The data were taken from the results of descriptive qualitative method. Techniques of data collection were interviews, observations, and library research. The result shows that kasambu is the ritual carried out by the Muna society for 7-8 first months of woman pregnancy. Nowadays, this ritual still exists although it has a difference in terms of employing medical services replacing sando's (traditional midwife) service. The ritual of kasambu is performed; so that the mother and the perspective child can avoid misfortune that may befall them and it can save in giving birth. The procession is a syncretism between the Islamic teaching followed and their ancestors' beliefs, where the sando was the person who knew the procedures for ceremony and the priest acted as the leader of the salvation prayer.
\end{abstract}

Keywords : kasambu, ritual, function, Muna society.

\section{PENDAHULUAN}

$\mathrm{S}$ etiap masyarakat mempunyai berbagai bentuk atau karakteristik tradisi ritualitas yang bersifat unik dan menjadi batas pembeda antara konsep tentang dunia dan pengalaman kesejarahan. Masing-masing komunitas etnik tersebut mempunyai pola-pola tradisi ritual yang berbeda namun mempunyai relevansi hubungan kultural dari sebuah pengalaman fase sejarah yang sama.
Muna salah satu etnik yang mendiami jazirah Sulawesi Tenggara dan memiliki keberagaman tradisi budaya sebagai warisan leluhurnya. Meskipun masyarakatnya telah mengalami serangkaian perubahan yang bersifat parsial maupun permanen dalam aspek sosial, ekonomi, politik, dan pendidikan sebagai sebuah konsekuensi dari fenomena global, tetapi bukan berarti sistem tradisi tidak lagi menjadi titik tempuh nilai bagi masyarakat untuk memandang dunia. 
Sejumlah tradisi yang terkait dengan upacara daur hidup (life cycle) pada masyarakat Muna hingga kini masih dilakukan oleh masyarakat pendukungnya, seperti kasambu, kangkilo(sunatan), katoba, karia, dan sebagainya. Setiap prosesi upacara yang dilakukan merupakan suatu perpaduan antara kepercayaan tradisional dengan sistem keyakinan yang dianut oleh masyarakatnya. Sinkretisme antara kepercayaan tradisional dengan agama yang dianut merupakan fenomena tersendiri, sehingga menarik untuk dijadikan sebagai sebuah tulisan.

Salah satu tradisi yang masih dipelihara, ditaati dan dipatuhi oleh masyarakat Muna yakni tradisi kasambu. Tradisi ini hingga sekarang masih ditaati, dipatuhi dan dilaksanakan oleh sebagaian masyarakat Muna, meskipun pada masa kekinian sudah mulai mengalami pergeseran, seperti penggunaan jasa sando pada saat melahirkan diganti oleh tenaga medis (bidan atau dokter). Namun demikian kasambu masih tetap dilakukan karena merupakan suatu tradisi yang tidak dapat ditinggalkan. Tradisi ini masih eksis dalam masyarakat Muna sebagai warisan budaya yang ditransmisi dari generasi ke generasi. Pelaksanaan upacara kasambu dimaksudkan agar orang tua dan anak selamat, serta terhindar dari ancaman malapetaka yang mungkin akan menimpanya. Khususnya bagi anak (bayi) yang masih berada di dalam kandungan dapat lahir dengan selamat. Sebagaimana yang diungkapkan oleh Thomas F. Odea (dalam Nuraeni, dkk, 2013:139-140), bahwa ritus berfungsi untuk melindungi individu dari rasa ragu dan bahaya dengan mengantisipasi serta mengatasinya secara simbolis, sehingga menenangkan kecemasan dari situasi bahaya pada orang-orang tanpa pegangan dan menghindari dari efek perusak yang dimilikinya.

Tradisi kasambu telah dikenal oleh masyarakat Muna sejak pra-Islam. Hal tersebut dapat dilihat pada saat pelaksanaan ritual, prosesinya dipimpin oleh sando dan imam (moji). Sando lebih berperan dalam mengatur tata cara dan perlengkapan upacara. Sedangkan imam berperan sebagai memimpin dalam pembacaan doa-doa untuk keselamatan bagi keluarga yang berhajat. Prosesi pelaksanaannya, bukan hanya si ibu hamil yang menjadi pelaku utama sebagaimana dalam upacara appassili pada masyarakat etnis Makassar atau maccera wettang pada masyarakat etnis Bugis, akan tetapi ayah dan ibu calon bayi turut pula dimandikan atau disucikan secara bersama-sama. Hal tersebut merupakan salah satu perlakuan khusus terhadap kedua orang tua calon bayi yang berbeda dengan pelaksanaan upacara yang sama pada daerah atau etnik lainnya.

Kasambu merupakan jenis ritus peralihan dalam siklus kehidupan manusia. Sebagaimana yang dikemukakan oleh Van Gennep dalam bukunya berjudul Les Rites de Passage (dalam Koentjaraningrat, 2007:75). bahwa dalam tahaptahap pertumbuhannya sebagai individu, yaitu sejak lahir, kemudian masa kanak-kanak, dewasa dan menikah, menjadi orang tua, hingga meninggal, manusia mengalami perubahan-perubahan biologi serta perubahan dalam lingkungan sosial budayanya yang dapat memengaruhi jiwanya dan menimbulkan krisis mental. Oleh karena itu, dalam lingkaran hidupnya manusia memerlukan "regenerasi" semangat kehidupan sosial.

Selamatan (slametan) atau upacara merupakan upaya manusia untuk mencari keselamatan, ketentraman. Selamatan merupakan upacara keagamaan paling umum di dunia, pesta komunal. Selamatan melambangkan kesatuan mistik dan sosial dari mereka yang ikut serta di dalamnya. Dalam pelaksanaan selamatan hadir keluarga, kerabat, tetangga, bahkan arwah nenek moyang yang sudah mati serta dewa-dewa. Semuanya duduk bersama, terikat dalam suatu kelompok sosial tertentu yang berikrar untuk saling tolong menolong dan bekerjasama (Geertz, 2013:3). Apa yang digambarkan oleh Geertz dalam penelitiannya pada masyarakat beretnis Jawa yang berkaitan dengan selamatan, hampir sama dengan tradisi kasambu pada masyarakat Muna. Di mana pelaksanaan kasambu terdapat pula tradisi tolong-menolong (pokadulu atau samaturu), balasmembalas (pabolosi).

Adapun yang menjadi fokus dalam tulisan ini adalah bagaimana prosesi pelaksanaan upacara kasambu, dan fungsinya bagi kehidupan sosial budaya masyarakat Muna? Sehubungan dengan itu tujuan penulisan ini diarahkan untuk mendeskripsikan prosesi pelaksanaan upacara kasambu, dan menganalisis fungsinya bagi kehidupan masyarakat Muna. Tulisan ini diharapkan dapat bermanfaat dalam kegiatan ilmiah maupun praktis. Dalam kegiatan ilmiah diharapkan dapat memberi kontribusi ilmiah dalam rangka pengembangan ilmu pengetahuan tentang budaya lokal masyarakat suku Muna di Sulawesi Tenggara. Sedangkan manfaat dalam kegiatan praktis, diharapkan dapat menjadi bahan masukan bagi pengambil kebijakan dalam rangka pelestarian 
dan pengembangan kebudayaan Indonesia.

Berkaitan dengan tradisi pelaksanaan upacara, maka dikemukakan beberapa teori-teori yang terkaitan dengan objek pembahasan. Suatu kebudayaan dapat dirumuskan sebagai seperangkat kepercayaan, nilai-nilai dan cara berlaku (kebiasaan) yang dipelajari dan pada umumnya dimiliki bersama oleh para warga dari suatu masyarakat (Ihromi, 2006:22). Menurut J.J. Honigmann dalam bukunya The World of Man (dalam Koentjaraningrat, 2009:150). bahwa kebudayaan itu ada tiga wujudnya, yaitu: (1) wujud kebudayaan sebagai suatu kompleks dari ide, gagasan, nilai, norma, peraturan dan sebagainya. (2) wujud kebudayaan sebagai suatu kompleks aktivitas serta tindakan berpola dari manusia dalam masyarakat. (3) wujud kebudayaan sebagai benda-benda hasil karya manuisa.

Manusia adalah makhluk sosial yang tidak bisa hidup sendiri, apa pun kapasitas dan kemampuannya. Karena itu manusia akan selalu hidup bersama dan bersesama dalam berbagai aspek. Dalam setiap masyarakat, baik yang kompleks maupun yang sederhana ada sejumlah nilai budaya satu dengan yang lainnya berkaitan hingga menjadi suatu sistem. Sistem itu sebagai pedoman dari konsep-konsep ideal dalam kebudayaan yang memberi motivasi kuat terhadap arah kehidupan warga masyarakatnya.

Defenisi konsep tentang kebudayaan yang diajukan oleh Geertz (dalam Daeng, 2008: v-vi), menunjuk kepada sistem simbol yang berfungsi untuk mengarahkan tingkah laku. Dalam pengertian di mana individu-individu mendefinisikan dunianya, menyatakan perasaannya dan memberikan penilaian-penilaiannya; suatu pola makna yang ditransmisikan secara historik diwujudkan di dalam bentuk-bentuk simbolik melalui sarana dimana orang-orang mengkomunikasikan, mengabadikannya, dan mengembangkan pengetahuan dan sikap-sikapnya ke arah kehidupan; suatu kumpulan peralatan simbolik untuk mengatur perilaku, sumber informasi yang ekstrasomatik". Karena kebudayaan merupakan suatu sistem simbolik, maka proses budaya haruslah dibaca, diterjemahkan, dan diinterpretasikan. Bentuk-bentuk simbol dianggap sebagai media penyimpanan makna, dan melalui simbol ini pula bisa dipahami "budaya" sekelompok orang. Budaya lebih menunjuk kepada pemahaman sekelompok orang terhadap hidupnya sebagai budaya generik yang merupakan blue print bagi tingkah laku.
Herskovits dan Malinowski (dalam Mujianto, dkk, 2010:2) menyebut kebudayaan dengan istilah cultural determinism, bahwa segala sesuatu yang terdapat dalam masyarakat ditentukan oleh kebudayaan yang dimiliki oleh masyarakat itu sendiri. Selanjutnya Herskovits menyebut kebudayaan sebagai superorganik, yaitu kebudayaan sebagai sesuatu yang turun temurun dari satu generasi ke generasi yang lain. Secara umum Sedyawati (2007:160-163) mengatakan bahwa kebudayaan dapat dibedakan menjadi yang bersifat fisik (tangible) dan nonfisik (intangible). Warisan budaya yang tangible yaitu yang dapat disentuh, berupa benda konkret, umumnya berupa benda yang merupakan hasil buatan manusia, dan dibuat untuk memenuhi kebutuhan tertentu, misalnya: candi, mesjid, gereja, pura, istana, rumah adat, alat-alat pertanian dan sebagainya. Sedangkan kebudayaan yang bersifat nonfisik (intangible) artinya yang tidak dapat diraba atau dipegang, dapat digolongkan pula ke dalam yang abstrak yang berada dalam alam pikiran manusia, misalnya tradisi, kepercayaan, kesenian, tari, sastra (lisan atau tertulis, prosa/puisi), musik, permainan dan olah raga tradisional, tata upacara, teknologi, dan ilmu pengetahuan.

Sistem nilai budaya merupakan bagian dari adat-istiadat dan wujud ideal dari kebudayaan, sistem nilai budaya seolah-olah berada di luar dan di atas diri para individu yang menjadi warga masyarakat yang bersangkutan. Sistem nilai budaya terdiri atas konsepsi-konsepsi yang hidup dalam alam pikiran sebagian besar warga masyarakat mengenai hal-hal yang mereka anggap amat bernilai dalam hidup (Koentjaraningrat, 2008:6). Selanjutnya C. Kluckhon dan Florence Kluckhon (dalam Koentjaraningrat, 2010:77), bahwa dalam rangka sistem budaya dari tiap kebudayaan ada serangkaian konsep-konsep yang abstrak dan luas ruang lingkupnya yang hidup dalam alam pikiran dari sebagian besar warga masyarakat yang dianggap penting dan bernilai dalam hidupnya. Sistem nilai budaya berfungsi sebagai suatu pedoman orientasi bagi segala tindakan manusia dalam hidupnya.

Sebagai konsepsi nilai adalah abstrak, sesuatu yang dibangun dan berada di dalam pikiran atau budi, tidak dapat diraba dan dilihat secara langsung dengan pancaindera. Nilai hanya dapat disimpulkan dan ditafsirkan dari ucapan, perbuatan, dan materi yang dibuat manusia. Ucapan, perbuatan, dan materi adalah manifestasi dari nilai. Nilai yang terkandung dalam suatu ucapan atau suatu perbuatan, perilaku 
dapat diketahui dengan melakukan penafsiran (interpretasi), dan penarikan kesimpulan (inferensi). Sebuah nilai adalah sebuah konsepsi, eksplisit atau implisit yang khas milik seseorang individu atau suatu kelompok tentang yang seharusnya diinginkan yang memengaruhi pilihan yang tersedia dari bentuk-bentuk, cara-cara, dan tujuan-tujuan tindakan (Marzali, 2005:115).

\section{METODE PENELITIAN}

Tulisan ini merupakan hasil penelitian dengan menggunakan pendekatan kualitatif deskriptif. Teknik pengumpulan data dilakukan melalui studi pustaka, wawancara, dan observasi. Dalam proses wawancara informan dipilih berdasarkan umur, dan pengetahuan yang dimiliki. Informan yang berusia lanjut dipilih atas dasar pertimbangan bahwa mereka memiliki pengalaman dan pengetahuan tentang fokus penelitian. Selain itu pula informan yang berusia muda dengan pertimbangan untuk mengetahui pendapat mereka tentang tradisi kasambu pada masa kekinian. Sando, imam, dan budayawan, dipilih dengan pertimbangan bahwa mereka mengetahui seluk beluk tentang kasambu.

Adapun yang diobservasi pada saat penelitian berlangsung antara lain: prosesi pelaksanaan upacara kasambu, pihak-pihak yang terlibat, tempat pelaksanaan upacara, benda-benda atau peralatan upacara, dan sebagainya.

Penelitian ini dilakukan di Kecamatan Duruka Kabupaten Muna Provinsi Sulawesi Tenggara. Dipilihnya lokasi tersebut karena didasarkan atas pertimbangan bahwa, umumnya masyarakat di wilayah tersebut masih melakukan tradisi kasambu, dan mempunyai keunikan tersendiri. Disamping itu, akses ke lokasi tersebut mudah dijangkau sehingga turut memperlancar prosesi penelitian.

\section{PEMBAHASAN}

\section{Sekilas tentang Wilayah Penelitian}

Kecamatan Duruka ${ }^{1}$ merupakan salah satu kecamatan dari 33 kecamatan yang ada di Kabupaten Muna. Wapunto merupakan ibu kota kecamatan, pemekaran dari Kecamatan Katobu. Kecamatan Duruka yang berjarak sekira 8 (delapan) kilometer dari Pelabuhan Nusantara Raha (ibu kota Kabupaten Muna), dapat dijangkau dengan menggunakan angkutan umum beroda empat (oto maengkuno) atau beroda dua (mentoro pisi).

Berdasarkan data yang tercatat di dalam

1 Kata Duruka merupakan istilah bahasa Muna yang berarti "hulu tombak" (wawancara dengan La Rimuni, 2014).
Kecamatan Duruka Dalam Angka (2013:1-5), bahwa secara administratif Kecamatan Duruka memiliki batas-batas wilayah: sebelah Utara berbatasan dengan Kecamatan Katobu; sebelah Selatan berbatasan dengan Kecamatan Lohia; sebelah timur berbatasan dengan Selat Buton; sebelah barat berbatasan dengan Kecamatan Kontunaga. Wilayah ini terdiri atas 7 (tujuh) desa/kelurahan, yaitu: Banggai, Lasunapa, Ghonsume, Wapunto, Gonebalano, Lagasa, Palangga. Luas wilayahnya sebesar $11,52 \mathrm{~km}^{2}$ atau sekitar $0,24 \%$ dari luas daratan Kabupaten Muna. Desa Banggai adalah desa yang terluas wilayahnya sekitar $2,65 \mathrm{~km}^{2}$ atau $23 \%$ dari luas wilayah Kecamatan Duruka. Sedangkan wilayah yang terkecil adalah Kelurahan Pallangga dan Desa Gonebalano masing-masing seluas 1,00 $\mathrm{km}^{2}$ atau sekitar 8,68\% dari luas Kecamatan Duruka. Penduduknya umumnya adalah penduduk asli Suku Muna. Jumlah penduduk Kecamatan Duruka pada awal tahun 2014 sebesar 11.631 jiwa atau sekitar 4,17\% dari jumlah penduduk Kabupaten Muna. Dari jumlah penduduk tersebut terdiri atas 5.657 jiwa penduduk berjenis kelamin laki-laki, dan 5.974 jiwa berjenis kelamin perempuan. Jumlah rumah tangga 2.571, dengan demikian rata-rata jiwa tiap rumah tangga sekitar 4.52 orang. Kepadatan penduduk $1.010 \mathrm{jiwa} / \mathrm{km}^{2}$. Kelurahan Wapunto merupakan yang terpadat penduduknya. Hal tersebut dapat dilihat dari luas wilayah yang dimiliki seluas 1.56 $\mathrm{km}^{2}$, dihuni sekitar 2.018 jiwa penduduk, kepadatan penduduk sekitar 1293,59 jiwa/ $\mathrm{km}^{2}$ (Kecamatan Duruka dalam Angka, 2013:12).

\section{Prosesi Kasambu}

\section{Nama dan Latar Belakang Upacara}

Dalam tradisi masyarakat Muna, jika kehamilan pertama bagi seorang perempuan yang telah menikah, selalu diadakan upacara kasambu. Sebagaimana dalam ungkapan yang berbunyi mahengga seghonu ghunteli, artinya, sekalipun hanya telur satu biji asalkan kasambu dilaksanakan. Kasambu merupakan tradisi yang telah mengakar dalam kehidupan masyarakat Muna. Menurut kepercayaan mereka bahwa setiap fase yang berkaitan dengan siklus kehidupan setiap individu merupakan sesuatu hal yang penting untuk dilakukan ritual untuk memperoleh keselamatan dan kebahagiaan. Kasambu merupakan upacara peralihan dalam siklus kehidupan masyarakat Muna. Sebagaimana yang dikemukakan oleh Arnold Van Gennep (dalam Daeng, 2008:145), bahwa dalam setiap masyarakat, kehidupan sosial secara berulang dengan interval 
tertentu memerlukan regenerasi. Setiap perubahan dalam pertumbuhannya, dapat terjadi krisis-krisis mental yang berpengaruh terhadap jiwa seseorang. Untuk itu diperlukan upacara penunjang siklus hidup seseorang.

Secara etimologi kata kasambu (Bahasa Muna) berasal dari kata sambu yang berarti suap, mendapat afiks $k a$ yang membentuk kata kerja. Dengan demikian, kata kasambu berarti melakukan kegiatan menyuapi atau memberi makan. Dalam hal ini memberi makan (menyuapi) kepada pasangan suami istri pada kehamilan pertama. Pada upacara kasambu, sando sebagai pemimpin upacara, merupakan orang pertama yang memulai menyuapi pasangan yang nesambu. Kemudian dilanjutkan oleh kedua orang tua, nenek, bibi, dan saudara dari masing-masing pasangan yang nesambu.

Upacara kasambu mulai dikenal masyarakat Muna sebelum masuknya ajaran Islam di Wilayah Muna. Setelah Islam masuk di wilayah tersebut sejak 1527 (pada masa pemerintahan Raja VI Sugi Manuru) kasambu tetap dilaksanakan oleh masyarakat, namun pelaksanaannya sudah dipadukan dengan ajaran Islam. Sebagaimana falsafah yang telah dikemukakan oleh Sugi Manuru yang berbunyi "nohansuru-hansuruana baja somano kono hansuru liwu; nohansuru-hansuruana liwu somano kono hansuru ajati" (artinya: biar hancur badan asal jangan hancur negeri; biar hancur negeri asal jangan hancur adat). Adat tetap berjalan dan bahkan menjadi peraturan tertinggi yang harus dijunjung. Kemudian pada masa pemerintahan La Ode Abdul Rahman (Sangia Latugho) yang memerintah tahun 1620-1665, falsafah tersebut ditambahkan, nohansu-hansurumo ajati sumono konohansuru agama (artinya: biar hancur adat asal agama jangan hancur). Dari falsafah tersebut bahwa yang menjadi pedoman bagi masyarakat yang paling tinggi adalah agama (Supriyanto, dkk, 2009:133).

\section{Maksud dan Tujuan Upacara}

Upacara kasambu termasuk upacara peralihan setiap individu dalam lingkaran kehidupannya (life cycle rites). Menurut Van Gennep (dalam Koentjaraningrat, 2007:74), bahwa ritus dan upacara religi secara universal pada azasnya berfungsi sebagai aktivitas untuk menimbulkan kembali semangat kehidupan sosial antarwarga masyarakat. Kehidupan sosial tiap masyarakat secara berulang dengan interval waktu tertentu, memerlukan "regenerasi" semangat kehidupan sosial masyarakat. Menurutnya di saat-saat tertentu semangat kehidupan sosial menurun, akibatnya akan menimbulkan kelesuan dalam masyarakat.

Di kebudayaan manapun manusia di dalam kehidupannya selalu terdapat saat yang penting. Apabila tiba saat meninggalkan satu tingkat dan memasuki tingkat kehidupan lain yang berada pada suasana yang berbahaya. Upaya untuk menolak bahaya itu manusia menciptakan usaha penyelamatan diri dengan mengadakan berbagai upacara. Upacara yang dilakukan, baik secara individual maupun kolektif adalah untuk berkomunikasi dan mengembangkan hubungan baik dengan para kekuatan gaib, hantu, setan, roh, dan sebagainya. Upacara tersebut dinamakan crisis rites atau rites de passage (upacara peralihan). Upacara-upacara tersebut berfungsi sebagai sarana pengumuman kepada khalayak ramai tentang tingkatan kehidupan yang telah dicapai seseorang (Koentjaraningrat, 1985:49).

Upacara kasambu pada masyarakat Muna dilaksanakan dalam suasana gembira dan keramat. Keluarga dari kedua pasangan calon ibu dan ayah, termasuk tetangga, ikut berpartisipasi, sekaligus memberikan doa keselamatan, memeriahkan upacara kasambu untuk mendorong rasa solidaritas di antara mereka. Upacara kasambu merupakan ritual individu atau keluarga yang bertujuan agar pasangan nesambu (orang yang dikasambu) dan bayi dalam kandungan dapat hidup bahagia dan selalu dalam lindungan Allah swt. Adapun maksud pelaksanaan kasambu dengan serangkaian prosesi agar bayi dapat lahir dengan selamat, lancar, dan kelak akan menjadi anak yang berbakti kepada orang tua. Selain itu, juga diharapkan agar ibu calon bayi tidak mengalami kesulitan sejak mengandung sampai melahirkan dengan selamat.

\section{Waktu dan Tempat Pelaksanaan Upacara}

Pada banyak kelompok etnik, dikenal adanya waktu atau jangka waktu tertentu yang dilihat dan dianggap sebagai suci atau sakral. Tempus sacrum atau waktu sakral dikatakan demikian karena orang yakin bahwa, dahulu pada waktu semacam itu telah terjadi peristiwa atau yang membawa keberuntungan atau kebahagiaan yang dinikmati oleh seluruh anggota kelompok etnik (Daeng, 2008:198). Pada pelaksanaan upacara kasambu juga terdapat waktu-waktu tertentu yang dianggap baik. Namun untuk menentukan waktu atau hari yang baik tersebut, biasanya harus dilakukan dengan 
kesepakatan keluarga yang berhajat dengan petunjuk sando dan iman. Salah seorang dari pihak keluarga calon bayi menghubungi sando (kabise sandono) dan imam untuk meminta petunjuk mengenai hari yang dianggap baik untuk melaksanakan kasambu. Sekaligus meminta kesediaan kepada kedua orang tersebut untuk memimpin pelaksanaan upacara kasambu.

Tempat pelaksanaan upacara kasambu juga ditentukan berdasarkan kesepakatan keluarga dari pasangan yang nesambu (orang yang dikasambu). Umumnya pasangan yang baru berkeluarga dan belum memiliki rumah sendiri, sehingga pelaksanaannya dilakukan di rumah keluarga pihak perempuan. Untuk prosesi siraman (dokadiuda) diadakan di luar rumah depan pintu dapur dan prosesi kasambu (saling menyuapi) diadakan di dalam rumah. Dipilihnya tempat siraman di depan pintu dapur rumah dimaksudkan sebagai simbol kemakmuran, dapur sebagai sumber makanan. Namun dengan perkembangan zaman, pada saat kekinian tempat prosesi siraman telah mengalami perubahan. Sebagian warga masyarakat Muna yang memiliki kamar mandi yang luas, memilih tempat tersebut sebagai tempat melaksanakan prosesi siraman (dokadiuda).

\section{Penyelenggara Upacara}

Penyelenggara upacara kasambu adalah seluruh kerabat dekat dari pasangan yang nesambu, baik dari pihak perempuan maupun laki-laki. Dalam pelaksanaannya yang bertindak sebagai pemimpin upacara (fosambuno) adalah sando dan imam. Sando bertugas memimpin jalannya upacara yang berkaitan dengan seluk beluk dan peralatan upacara, sedangkan imam, adalah orang yang dianggap memiliki pengetahuan yang berkenaan dengan doa-doa. Dialah yang memimpin prosesi siraman (dokadiuda) yang diawali dengan doa-doa untuk keselamatan calon ibu dan bayi yang ada di dalam kandungannya. Pasangan calon orang tua bayi adalah orang yang melaksanakan upacara kasambu. Selain itu, terdapat dua orang pendamping (laki-laki dan perempuan) yang disebut dokundedo bertugas keramas orang yang nesambu. Peserta yang turut hadir pada upacara terdiri atas keluarga, kerabat terdekat khususnya kaum perempuan yang sudah dewasa, dan umumnya berjenis kelamin perempuan. Selain itu, beberapa orang yang sengaja diundang, seperti imam dan beberapa pengurus masjid untuk membacakan kitab al-barazanji dan doa-doa (zikir).

\section{Persiapan dan Perlengkapan Upacara}

Setiap ritual yang akan diselenggarakan baik secara individu ataupun kelompok, terdapat beberapa ketentuan yang perlu mendapat perhatian. Sebelum pelaksanaan upacara kasambu, pihak keluarga terlebih dahulu mempersiapkan segala sesuatunya yang akan digunakan. Adapun yang harus dipersiapkan adalah kebutuhan pokok berupa bahan haroa, seperti ketupat (katopa), ayam, telur, dan gula merah. Sedangkan kebutuhan untuk siraman (dokadiuda) dipersiapkanlesung (katumbu), sarung (bheta), air dua cerek (deferebuanda oe ra sere), mayang kelapa (boru/bale kalapa) kelapa, dan daun nangka atau daun kombau. Apabila tempat pelaksanaan siraman dilakukan di kamar mandi, maka yang harus dipersiapkan adalah dua buah kursi sebagai tempat duduk nesambu (orang yang dikasambu), dan daun pisang sebagai alas kaki. Untuk prosesi kasambu (disuap) perlengkapan yang harus dipersiapkan berupa sarung (bheta), bantal, kain putih (kai kapute), tikar (ponda), serta parang yang akan digunakan pada saat kasungki (cungkil). Demikian pula untuk perlengkapan pembacaan doa dipersiapkan seperangkat alat pedupaan. Sebagai persiapan akhir (sehari menjelang pelaksanaan upacara), pihak keluarga yang menyelenggarakan upacara, mulai memasak berbagai jenis makanan, seperti: ketupat, ayam, aneka jenis kue, dan air gula. Jenis-jenis makanan tersebut nantinya akan ditata dalam baki (haroa) sebelum disuguhkan ke nesambu dan peserta upacara yang hadir.

\section{Jalannya Upacara Kasambu}

Pada hari yang telah ditentukan, pasangan suami istri yang akan dikasambu duduk di atas lesung (katumbu) yang telah dipersiapkan dengan memakai sarung (bheta) sebatas dada (kabonto) tanpa memakai baju. Sarung yang dipakai itu, di dalamnya dilapisi kain berwarnah putih (kae kapute) sebagai simbol kesucian dan bersih. Hal itu juga dimaksudkan agar jabang bayi di dalam kandungan dapat lahir dengan selamat tanpa cacat.

Saat pasangan calon orang tua bayi duduk di atas lesung (katumbu), petugas keramas (dokundedo) mulai mengerjakan tugasnya masingmasing dipandu oleh sando. Dokundedo moghanehi (pendamping laki-laki) bertugas keramas calon

2 Prosesi yang dilakukan sebagai tanda bahwa upacara kasambu selesai, dimana sando mencungkil dengan menggunakan ujung parang pada salah satu sudut bantal yang diduduki oleh nesambu. Setelah kasungki, pasangan nesambu diperbolehkan berdiri dari tempat duduknya. 
ayah si jabang bayi dan dokundedo robhinehi (pendamping perempuan) bertugas keramas calon ibu. Bahan yang digunakan untuk keramas terbuat dari santan kelapa. Setelah pasangan calon orang tua bayi tersebut dokadiuda dosuawida (dikeramas dan disisir), maka dilanjutkan dengan prosesi siraman (dokadiuda).

Gambar 1. Prosesi siraman (dokadiuda)

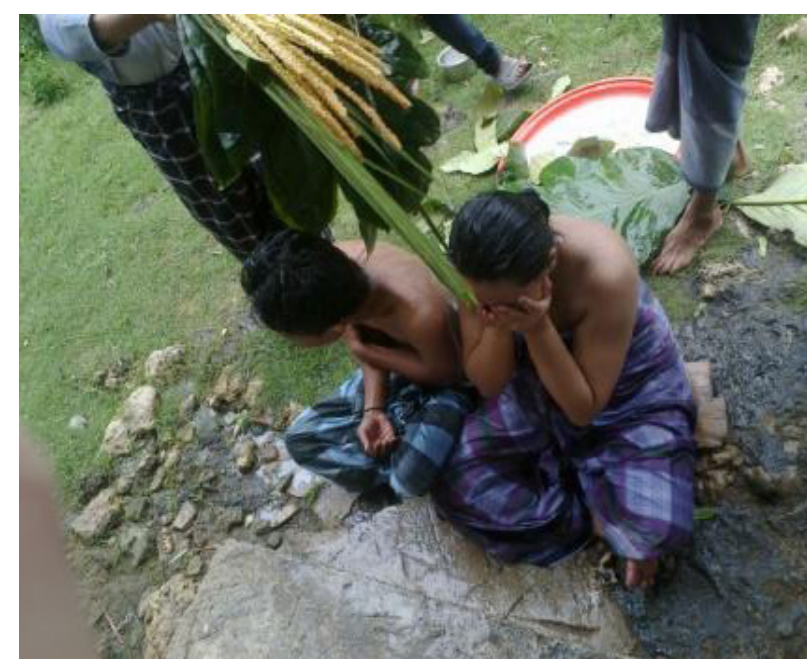

Sumber: Dokumentasi keluarga Hikmah.

Dalam prosesi siraman (dokadiuda) tersebut air yang akan diguanakan untuk memandikan atau menyiramkan kepada kedua pasangan suami isteri, terlebih dahulu diberi bacaan doa oleh imam. Jika pembacaan doa tersebut selesai, maka mulailah dilakukan siraman oleh imam dibantu sando yang bertugas memegang seikat mayang kelapa (bale kalapa) dan daun nangka sebagai luncuran air. Pada saat akan memulai siraman (dokadiuda) posisi pasangan suami isteri yang nesambu harus mengahadap ke Barat (kasopa). Setelah itu, mulailah air disiramkan melalui seikat bale kalapa dan daun nangka, dimulai dari ayah calon bayi lalu ke ibu calon bayi. Air siraman yang mengucur ditadah dengan tangan kiri oleh pasangan calon orang tua bayi, lalu dibuang ke belakang. Perlakukan itu dilakukan sebanyak tiga kali sebagai simbol menolak bala, dan simbol ajaran Islam, bahwa berwuduh dilakukan sebanyak tiga kali. Setelah air siraman satu cerek habis, pasangan nesambu mengganti posisi duduk dengan menghadap ke Timur (mata gholeo). Setelah itu siraman kembali dilanjutkan dengan air yang telah disediakan dalam satu cerek. Siraman pertama tetap dimulai dari calon ayah lalu kemudian ke calon ibu. Pada saat siraman berlangsung, pasangan suami isteri menadah air yang mengucur dengan tangan kanan lalu dibasuhkan ke ubun-ubun masingmasing. Perlakuan itu dilakukan sebanyak tiga kali dengan niat mudah-mudahan diberi keselamatan oleh Allah. Setelah prosesi siraman (dokadiuda) selesai, tahap berikutnya adalah katobesi, yaitu kelapa yang telah disiapkan sebelumnya dibelah oleh sando, lalu airnya disiramkan kepada pasangan yang nesambu. Katobesi dimaksudkan sebagai simbol pecahnya ketuban calon ibu yang nesambu. Selanjutnya belahan kelapa yang dipegang oleh sando dilempar atau dibuang ke tanah. Apabila kedua belahan kelapa tersebut atau salah satunya ada yang terkelungkup, maka itu pertanda akan terjadi musibah bagi keluarga nesambu. Untuk mengangkat kedua potongan kelapa tersebut harus dilakukan oleh kunde (pendamping nesambu) dengan cara digigit. Kunde terbagi dua yaitu, kunde moghanehi (pendamping laki-laki) bertugas mengangkat dengan cara menggigit potongan kelapa bagian atas (fortuno) dan kunde robhinehi (pendamping perempuan) bertugas menggigit potongan kelapa bagian bawah (korono). Pada saat potongan kelapa digigit oleh kunde serentak peserta upacara bersuara seperti mengusir hewan. Hal itu sudah menjadi tradisi bagi mereka, karena potongan kelapa itu disimbolkan sebagai tumbal dari segala malapetaka bagi pasangan suami istri itu.

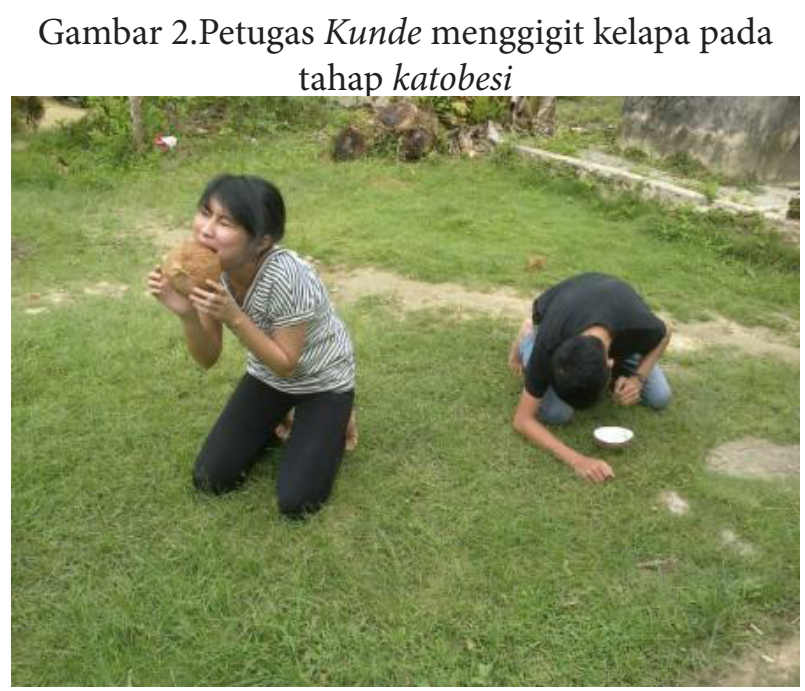

Sumber: Dokumentasi keluarga Hikmah.

Setelah prosesi siraman (dokadiuda) yang dilakukan di luar rumah, di depan pintu dapur. Prosesi selanjutnya akan dilakukan di dalam rumah. Sebelum masuk ke dalam rumah, pasangan suami istri nesambu mengganti sarungnya (dofosukoanda bheta) yang telah basah dengan sarung yang kering. 
Selanjutnya dituntun oleh ibu mertua masuk ke dalam rumah (dofofonida selolambu). Kemudian mengenakan pakaian (dofopakeda), berupa baju (laki-laki), kebaya (perempuan) tidak dikancing yang dipadu dengan sarung sebatas dada (kabonto). Nesambu duduk di atas bantal beralas kain putih (kai kapute) dan tikar (ponda) dihadapan haroanya (aneka jenis makanan yang ditata diatas baki (dula)), seperti ketupat,(katopa) dua jenis, yaitu katopa titi yang menyerupai buah dada perempuan dan katopa langole yang menyerupai alat reproduksi laki-laki, telur (ghunteli), manisan (air gula merah), ayam rebus, cucur (susuru), waje, pisang, serta rujak.

Prosesi nesambu dimulai pembacaan kitab Albarazanji dan dzikir oleh pengurus masjid. Kemudian dilanjutkan dengan pembacaan doa yang dipimpin oleh imam. Selanjutnya imam bersalaman dengan nesambu (dopointaramo lima oimamua nosambu damo) sebagai pertanda pembacaan doa telah selesai. Prosesi selanjutnya adalah menyuap pasangan calon orang tua jabang bayi (nosambu damo) yang dipimpin oleh sando. Pertama-tama yang disuap ialah calon ayah (nesambu moghane) dengan katopa titi (ketupat yang menyerupai model buah dada perempuan). Kemudian calon ibu bayi (nesambu robhine) disuap dengan katopa langole (ketupat yang modelnya menyerupai alat reproduksi laki-laki). Pada suapan pertama yang digigit hanya pada bagian sudut ketupat, lalu dibuang ke arah kanan dan kiri masing-masing pasangan nesambu. Hal itu dilakukan sebagai simbol membuang atau menolak hal-hal yang kurang baik yang kemungkinan akan menimpa pasangan nesambu beserta bayi yang ada di dalam kandungan. Setelah itu, sando melanjutkan menyuap nesambu, mulai dari katopa, lalu telur (ghunteli) yang harus dimakan utuh oleh nesambu, aneka jenis kue tradisional. Setiap makanan yang akan disuap kepada nesambu selalu dicelup ke dalam air gula (neegola). Hal tersebut dilakukan dengan maksud agar nesambu dan bayi dalam kandungan selamat dan sejahtera. Adapun sisa makanan dari nesambu diberikan kepada kunde (pendamping) dan pihak keluarga atau anak-anak yang hadir di tempat itu.

Setiap perlakuan yang ada di dalam hampir semua upacara tradisional terdapat simbol-simbol yang melambangkan sesuatu yang bermakna bagi pendukungnya. Demikian halnya di dalam prosesi kasambu, perlakuan-perlakuan sando memiliki makna tersendiri bagi pendukungnya. Seperti pada saat menyuap nesambu, sando menggunakan tangan kanan memegang makanan yang akan disuap kepada nesambu, sementara tangan kirinya menopang siku tangan kanannya. Hal itu sebagai simbol, bahwa siku tidak pernah kaku mudah digerakkan bagaikan rezeki yang selalu lancar, dan segala malapetaka yang akan menimpa keluarga nesambu selalu dapat ditangkis (disiku).

Keluarga baru mendapat giliran menyuapi nesambu setelah sando selesai melaksanakan prosesi ritualnya. Diawali dari pihak nenek dari masingmasing nesambu, kemudian ibu dan mertua, disusul dari garis tante, dan saudara, serta kerabat lainnya. Pada prosesi nesambu ini identik dengan upacara perempuan, karena umumnya pesertanya dari kaum perempuan. Setelah prosesi nesambu selesai, dilanjutkan dengan acara pemberian hadiah dari keluarga. Hadiah berupa uang dan perlengkapan melahirkan, seperti sarung dan pakaian bayi. Orang pertama yang memberikan hadiah kepada pasangan nesambu ialah keluarga dari pihak calon ayah baru keluarga dari pihak calon ibu, mulai dari nenek, tante, sepupu, dan saudara. Selain hadiah dari pihak kelurga, juga dari kerabat.

\section{Pantangan-Pantangan yang Harus Dihindari}

Suatu upacara yang bersifat sakral magis biasanya memiliki beberapa komponen yang bersifat pantangan atau pamali. Demikian pula pada tradisi upacara kasambu terdapat beberapa pantangan yang harus dihindari oleh penyelenggara upacara. Seperti yang tercermin pada perlengkapan atau bahan upacara serta pada perlakuan pada pelaksanaan upacara. Adapun pantangan dengan perlengkapan upacara, yakni air yang akan dipakai siraman (dokadiuda), tidak boleh langsung digunakan jika tidak terlebih dahulu dibacakan doa oleh imam. Hal itu dimaksudkan agar air siraman dapat membawa berkah. Begitupun ketika bayi dilahirkan dapat keluar dengan lancar bagaikan air yang mengalir. Juga yang menjadi perhatian bagi penyelenggara upacara yaitu pada haroa-nya (beberapa jenis makanan yang ditata dalam baki yang diperuntukkan pasangan nesambu, seperti ketupat, telur, air gula ayam, dan kue-kue tradisional) pantang dimakan oleh orang lain sebelum nesambu selesai disuap. Pelanggaran terhadap hal tersebut dapat menyebabkan anak lahir dengan cacat. Pantangan lainnya, yakni pendamping nesambu (kunde) disyaratkan harus dari orang yang masih hidup kedua orang tuanya. Bilaman hal tersebut dilanggar dapat menyebabkan salah satu dari orang tua si calon bayi meninggal, dan bayi akan lahir dengan cacat. Begitupun terhadap buah kelapa yang 
telah dibelah, juga pantang dimakan di tempat itu, dan tidak boleh kena asap ataupun dijemur. Karena itu pelanggaran terhadap pantangan tersebut dapat menyebabkan anak yang masih dalam kandungan kulitnya akan keriput.

Sementara itu, pantangan-pantangan yang terkait dengan prosesi upacara juga dapat dikemukakan, seperti nesambu pantang mengenakan pakaian yang dikancing. Pantangan ini perlu dihindari agar anak dapat lahir dengan lancar tanpa ada hal-hal yang menghalangi. Pantangan lainnya, yakni nesambu pantang menggaruk badan pada saat prosesi siraman (dikadiuda). Pelanggaran pada pantangan tersebut akan menyebabkan anak terkena penyakit gatal-gatal. Demikian pula sarung yang telah dipakai siraman, pantang diperas airnya. Sebab bilaman hal tersebut dilakukan dapat menyebabkan jabang bayi dalam kandungan akan terlilit tali pusar sehingga sulit dilahirkan. Pantangan lainnya, yakni saat prosesi kasambu selesai, nesambu tidak dibolehkan berdiri sebelum ke empat sudut bantal yang telah diduduki disungki (cungkil) dengan parang oleh sando atau imam sebagai orang yang memimpin jalannya upacara (fosambuno). Ini dimaksudkan agar jabang bayi di dalam kandungan dapat lahir dengan lancar dan selamat.

\section{Fungsi Tradisi Kasambu pada Masnyarakat Muna}

Pemakaian kata fungsi dalam ilmu antropologi, diartikan untuk menerangkan hubungan yang terjadi antara satu hal dengan hal-hal lain dalam suatu sistem yang terintegrasi. Sebagai contoh, perubahan suatu organisme akan menyebabkan perubahan pada beberapa bagian organisme lain, dan bahkan dapat pula menyebabkan perubahan pada seluruh bagian organisme tersebut (Spiro dalam Poerwanto, 2008:143). Selain itu, Spiro (dalam Koentjaraningrat, 2009:173) mengemukakan cara pemakaian kata fungsi itu sebagai hubungan antara suatu hal dengan suatu tujuan tertentu (misalnya, mobil mempunyai fungsi sebagai alat angkut manusia atau barang), dan menerangkan kaitan antara satu hal dengan hal lain (misalnya, kalau nilai dari satu hak $\mathrm{x}$ itu berubah, maka nilai dari satu hal lain yang ditentukan oleh $\mathrm{x}$ tadi juga berubah).

Salah satu fungsi dari ritual religi atau agama pada umumnya ialah untuk mengintensifkan solidaritas masyarakat, Robertson Smith (dalam Koentjaraningrat, 2007:67). Ritus dan ritual adat sebagai kegiatan sosial, biasanya melibatkan para warga masyarakat dalam usaha bersama untuk mencapai tujuan keselamatan bersama. Kerjasama antar warga masyarakat itu sesuai dengan kodrat manusia sebagai mahluk sosial. Adapun ritus dan ritual adat ini merupakan bagian yang integral dari kebudayaan masyarakat pendukungnya, karena memiliki fungsi yang dapat dirasakan untuk memenuhi suatu kebutuhan baik secara individual maupun kelompok. Dalam penyelenggaraannya, ritus dan ritual adat dapat mengikat rasa solidaritas para warga masyarakat. Mereka merasa memiliki kepentingan bersama, dan merasa berasal dari leluhur yang sama, sehingga rasa solidaritas semakin erat.

\section{Fungsi Sosial}

Mauss (dalam Koentjaraningrat, 2007:102105) menggambarkan hasil penelitiannya yang berkaitan dengan kehidupan masyarakat Eskimo, mengatakan bahwa solidaritas sosial dari suatu masyarakat itu dapat mengendor dan menjadi intensif lagi menurut musim, sehingga perlu ada usaha-usaha khusus untuk berulang-ulang mengintensifkan kembali solidaritas sosial itu. Sentimen agama merupakan salah satu kekuatan penting untuk mengintensifkan kembali solidaritas sosial dalam masyarakat.

Terkait dengan pendapat tersebut di atas, di dalam tradisi kasambu tampak adanya solidaritas di antara para pendukung upacara kasambu. Mereka saling bantu-membantu (tulumie khabhu) baik dalam bentuk materi maupun berupa tenaga. Senada dengan hasil penelitian Geertz (2013:81) pada masyarakat di Mujokuto bahwa, pada upacara slametan sebuah hubungan timbal balik terlepihara. Setiap orang yang menyumbangkan tenaga pada slametan si perempuan hamil beserta suaminya berhak meminta bantuan tenaga sekitar sehari untuk maksud yang sama dikemudian hari. Kewajiban semacam itu, tidak peduli betapapun rumitnya selalu saja diingat orang.

Selain itu juga terdapat pertukaran timbal balik (resiprositas) antara sesama pendukung kasambu. Menurut Dalton (dalam Sairin, 2002:42) bahwa resiprositas merupakan pola pertukaran sosial-ekonomi, di mana individu memberikan dan menerima barang atau jasa karena kewajiban sosial. Terdapat kewajiban orang untuk memberi, menerima, dan mengembalikan kembali pemberian dalam bentuk yang sama atau berbeda.

Sudah menjadi tradisi di kalangan mereka, bahwa setiap ada yang mengadakan hajatan, mereka saling membantu berupa tenaga maupun materi 
(uang). Semua sumbangan yang diterima dicatat (deburie). Ketika suatu waktu si pemberi sumbangan juga mengadakan acara yang sama, maka orang yang telah disumbang harus membalas (pobolosi), minimal jumlahnya sama dengan sumbangan yang pernah diterimanya. Polanyi (dalam Sairin, 2002:44) mengungkapkan bahwa, resiprokal (rasa timbal balik) sangat besar difasilitasi oleh bentuk simetri institusional. Dengan demikian tanpa adanya hubungan simetri antarkelompok atau antarindividu, maka resiprositas tidak akan berlangsung.

\section{Fungsi Spiritual}

Masyarakat suku bangsa Muna termasuk salah masyarakat yang masihcukupkuat mempertahankan tradisinya. Unsur-unsur kepercayaan tradisional yang dimiliki dipadukan dengan ajaran agama Islam yang dianutnya. Agama dan kepercayaan tradisional terintegrasi dalam kehidupan masyarakat. Ritual keagamaan dilaksanakan sebagai manifestasi dari kebudayaan yang mereka miliki. Sehubungan dengan hal tersebut. Durkheim (dalam Koentjaraningrat, 2007:94-95) mengemukakan bahwa walaupun manusia sekarang sudah banyak menemukan kekuatan yang menguasai hidupnya dalam alam sekitarnya, religi dan agama belum terdesak dari kehidupan manusia. Suatu religi itu adalah siatu sistem berkaitan dari keyakinan-keyakinan dan upacara-upacara yang keramat (sacred) artinya yang terpisah dan pantang, keyakinan-keyakinan dan upacara yang berorientasi kepada suatu komunitas moral yang disebut umat.

Geertz (dalam Sutiyono, 2010:37-38) menyebutkan bahwa, agama adalah suatu sistem simbol yang berfungsi untuk mengukuhkan suasana hati dan motivasi yang kuat dan mendalam pada diri manusia dengan menformulasikan konsepsi tentang tatanan umum eksistensi dan membungkus konsepsi itu dengan aura aktualitas yang bagi perasaan dan motivasi tampak realistis. Lebih jauh dikatakan bahwa, sistem simbol keagamaan dapat dielaborasi melalui berbagai cara. Cara yang umum dipakai kebanyakan agama adalah melalui ritual. Melalui ritual inilah dunia sebagaimana yang dibayangkan (as imagined) dan dunia sebagaimana yang dialami (as lived) dipadukan melalui perbuatan-perbuatan dalam bentuk simbol.

\section{Fungsi Ekonomi}

Sistem ritual keagamaan secara khusus mengandung empat aspek yang menjadi perhatian bagi para antropologi, yaitu (1) tempat ritual dilakukan; (2) saat-saat ritual dilaksanakan; (3) benda-benda dan alat ritual; (4) orang-orang yang terlibat dalam ritual (Koentjaraningrat, 2009:296). Sejalan dengan hal tersebut dalam setiap pelaksanaan ritual memerlukan persiapan-persiapan yang tentunya membutuhkan modal, baik dalam bentuk materi (uang) maupun berupa nonmateri (tenaga).

Pada pelaksanaan kasambu memerlukan bahan-bahan haroa (aneka jenis makanan untuk nesambu), bahan-bahan tersebut diperoleh dengan cara membeli. Selain itu untuk pangadaan makanan tersebut membutuhkan proses mengolahnya yang tentunya membutuhkan tenaga.

\section{Fungsi Ekologi}

Manusia dan lingkungannya sebagai suatu jaringan yang amat kompleks, dan terwujud dalam sistem religi. Para ahli antropologi juga menyadari bahwa alam sekitar akan memengaruhi kebudayaan, sekalipun tidak selalu negatif (Rapport dalam Poerwanto, 2008:73).

Kebudayaan merupakan fenomena yang selalu berubah sesuai dengan alam sekitarnya dan keperluan suatu komunitas. Seperti halnya dengan makhluk-makhluk hidup lainnya, agar dapat tetap mempertahankan hidupnya, maka manusia harus selalu menjaga hubungan adaptasi dengan ekosistemnya. Adaptasi mengacu pada proses interaksi antara perubahan yang ditimbulkan oleh lingkungan, dan perubahan yang ditimbulkan oleh lingkungan dari organisme tersebut (Poerwanto, 2008:61).

Hubungan adaptasi dengan lingkungan bagi masyarakat pendukung kasambu dapat dilihat pada bahan atau perlengkapan upacara kasambu. Masyarakat pendukung kasambu memerlukan beberapa perlengkapan upacara dari sekitar lingkungannya, seperti penggunaan pucuk kelapa (bale), daun nangka, dan daun pisang. Ketika upacara kasambu selesai, sisa makanan nesambu (seperti ketupat) diyakini oleh mereka sebagai penyubur tanaman.

\section{PENUTUP}

Kasambu merupakan tradisi masyarakat Muna yang ditransmisi dari leluhur mereka ke generasi masa kini. Tradisi ini dikenal oleh masyarakat Muna 
sebelum masuknya ajaran agama Islam. Setelah ajaran agama Islam masuk di wilayah tersebut (tahun 1527), tradisi ini dilaksanakan dengan perpaduan antara kepercayaan leluhur mereka dengan ajaran agama Islam yang dianutnya. Sando (kepercayaan tradisional) adalah orang yang dianggap mengetahui tata cara dan perlengkapan upacara, sedangkan imam (ajaran agama Islam) adalah pemimpin doa dalam upacara tersebut. Berbeda pada masa lalu, jasa sando dibutuhkan pada awal kehamilan sampai pasca melahirkan. Namun pada saat ini, menjelang melahirkan umumnya meminta bantuan kepada tenaga medis (bidan atau dokter). Upacara ini merupakan jenis upacara individu atau keluarga, oleh karena itu pesertanya hanya sebatas kalangan keluarga saja. Kasambu hanya dilaksanakan pada kehamilan pertama seorang perempuan.Tradisi ini dilakukan sebagai rasa syukur atas kehamilan seorang perempuan dan sebagai upaya untuk memohon keselamatan kepada Tuhan agar ibu dan anak dapat lahir dengan selamat.

Prosesi kasambu diawali dengan noforatoe, yaitu pihak keluarga pasangan nesambu mengadakan musyawarah untuk pelaksanaan kasambu. Kemudian kabasi sandono dan imam (meminta kesediaan dukun dan imam) untuk memimpin kasambu. Setelah waktu yang telah disepakati bersama antara keluarga nesambu, imam, dan sando, maka prosesi kasambu diadakan. Prosesi siraman diadakan di luar rumah, di depan pintu dapur. Diawali dengan pembacaan doa yang dipimpin oleh imam. Ritual selanjutnya dipimpin oleh sando, dimulai dengan dekunde (dikeramas), lalu dokaiuda (siraman), dikatobesi. Setelah prosesi siraman selesai, acara selanjutnya dilakukan di dalam rumah nesambu. Prosesi disambu (disuap) diawali dengan pembacaan doa oleh imam. Kemudian dilanjutkan oleh sando memimpin ritual menyuap (disambu) kepada pasangan nesambu. Sebelum pasangan nesambu berdiri, sando atau imam mencungkil (kasungki) keempat sudut bantal yang diduduki oleh nesambu. Upacara ini ditutup dengan makan bersama.

Sampai saat ini, tradisi ini masih bertahan pada masyarakat Muna karena memiliki beberapa fungsi, seperti fungsi sosial, spritual, ekonomi, dan ekologi.

\section{UCAPAN TERIMA KASIH}

Ucapan terima kasih disampaikan kepada Kepala Balai Pelestarian Nilai Budaya Makassar, rekan-rekan peneliti, dan seluruh informan atas segala bantuannya dalam memperoleh data. Ucapan yang sama kepada Bapak Prof. Dr. Yamin Sani, M.Si. yang telah memberikan bimbingan kepada peneliti mulai pembahasan desain penelitian hingga penulisan laporan hasil penelitian. Terima kasih pula kepada Tim Redaksi Al-Qalam atas diterbitkannya artikel ini.

\section{DAFTAR PUSTAKA}

Anonim. 2013. Kecamatan Duruka dalam Angka. Kabupaten Muna: Badan Pusat Statistik.

Daeng, Hans J. 2008. Manusia, Kebudayaan dan Lingkungan Tinjauan Antropologis. Yogyakarta: Pustaka Pelajar.

Geertz, Clifford. 2013. Agama Jawa: Abangan, Santri, Priyai dalam Kebudayaan Jawa. (Terjemahan Aswab Mahasin dan Bur Rasuanto) Jakarta: Komunitas Bambu.

Ihromi (ed). 2006. Pokok-Pokok Antropologi Budaya. Jakarta: Yayasan Obor Indonesia.

Koentjaraningrat. 2007. Sejarah Teori Antropologi I. Jakarta: Penerbit Universitas Indonesia Press. --.-. 1985. Ritus Peralihan di Indonesia. Jakarta: Balai Pustaka.

-----. 2009. Pengantar Ilmu Anropologi.

Jakarta: Rineka Cipta.

---.-. 2010. Sejarah Teori Antropologi II. Jakarta:Penerbit Universitas Indonesia Press. ----.-. 2008. Kebudayaan Mentalitas dan Pembangunan. Jakarta: Gramedia Pustaka Utama.

Marzali, Amri. 2005. Antropologi dan Pembangunan Indonesia. Jakarta: Prenada Media.

Mujianto, Yan, Zaim Elmubarok, Sunahrowi. 2010. Pengantar Ilmu Budaya. Yogyakarta: Pelangi Publising.

Nuraeni, Heny Gustini dan Muhammad Alfan. 2013. Studi Budaya di Indonesia. Bandung: Pustaka Setia.

Poerwanto, Hari. 2008. Kebudayaan dan Lingkungan dalam Perspektif Antropologi. Yogyakarta: Pustaka Pelajar.

Sairin, Sjafri, dkk. 2002. Pengantar Antropologi Ekonomi. Yogyakarta: Pustaka Pelajar.

Sedyawati, Edi. 2007. Budaya Indonesia: Kajian Arkeologi, Seni, dan Sejarah. Jakarta: Raja Grafindo Persada.

Sutiyono. 2010. Benturan Budaya Islam:Puritan dan Sinkretis. Jakarta: Penerbit Buku Kompas.

Supriyanto, dkk. 2009. Sejarah Kebudayaan Islam 
Sulawesi Tenggara. Kerjasama Kantor Wilayah Departemen Agama Provinsi Sulawesi Tenggara dengan Universitas Muhammadiyah Kendari. 